DOI: 10.34015/2523-4552.2020.4.18

удк 340.1

Шевченко А. $\epsilon$.,

доктор юридичних наук, професор, заслужений юрист України, завідувач кафедри теорії, історії права і держави та конституційного права Університету державної фіскальної служби України ORCID: 0000-0003-2663-9892

\title{
КОНСТРУЮВАННЯ ІСТОРИЧНОГО МИНУЛОГО ОРГАНІВ ДЕРЖАВНОЇ ВЛАДИ ТА УПРАВЛІННЯ КРІЗЬ ПРИЗМУ СУЧАСНИХ ІНСТИТУЦІЙНИХ ЗМІН
}

Рецензія на кн.: Дудченко О. С. Конституційно-правові засади створення й функціонування органів державної влади та управління радянської України в 1920-х - першій половині 1930-х років: монографія; за заг. ред. д. ю. н., професора Г. В. Лаврик. Ніжин : НДУ ім. М. Гоголя, 2019. 405 с.

Монографія присвячена актуальній темі, яка довгий час досліджувалася через призму марксистколенінської ідеології. Актуальність проблеми формування органів державної влади УСРР-УРСР завжди становили значний науковий інтерес для дослідників. Проте, конституційно-правові засади створення та функціонування органів державної влади та управління УСРР потребують окремого дослідження. Відтак монографія О.С. Дудченко заповнює помітну прогалину в українській юридичній науці.

Наукові положення, висновки та рекомендації автор обгрунтовує, використовуючи значну кількість маловідомих широкому науковому загалу архівних документів і матеріалів. Дослідником фундаментально опрацьовані нормативно-правові акти СРСР та УСРР зазначеного періоду, протоколи засідань окремих органів державної влади та управління ра- дянської України та матеріали до них, що зберігаються в Центральному державному архіві громадських об'єднань України, Центральному державному архіві вищих органів влади і управління України, державних обласних архівах України.
Монографія
О. С. Дудченко «Конституційно-правові засади створення й функціонування органів державної влади та управління радянської України в 1920-х - першій половині 1930-х років» присвячена дослідженню конституційно-правових засад створення та функціонування органів державної влади та управління УСРР-УРСР зазначеного періоду, аналізові їх організаційної структури, форм та методів діяльності.

Автор систематизує та узагальнює наявні теоретичні та концептуальні підходи до розуміння понять «механізм держави» та «орган держави», з'ясовує ступінь наукової розробки теми в сучасній історико- 
правовій науці. Використовуючи проблемно-хронологічний підхід, автор поділяє історіографічний доробок учених із проблем створення та функціонування органів державної влади та управління радянської України на кілька груп.

Чимала увага у роботі присвячена характеристиці правових засад становлення та розвитку законодавчих органів державної влади та управління УСРР за Конституцією УСРР 1919 р. та аналізові правового регулювання формування народних комісаріатів УСРР як центральних органів державного управління у різних сферах суспільного життя.

У монографії розглядається еволюція організаційної структури органів державної влади та управління УСРР, аналізуються її повноваження. Зокрема, авторами доведено, що організаційна структура органів державної влади та управління в загальних рисах сформувалася відповідно до Конституції УСРР 1919 р. й у подальшому принципових змін не зазнавала. Реформування організаційної структури органів державної влади та управління радянської України відбулося відповідно до Конституції радянської України $1937 \mathrm{p}$.
Підкреслимо, що на основі архівних матеріалів, проведено аналіз кількісного та якісного складу органів державної влади та управління УСРP.

Також у монографії досліджується форми і методи діяльності органів державної влади та управління радянської України в зазначений період, класифікуються та аналізуються їх види.

Водночас, під час характерники конституційно-правові засади створення та діяльності органів державної влади та управління радянської України в 1920 - 1930-х рр., з'являється можливість детально проаналізувати особливості створення та функціонування місцевих органів влади УСРР в зазначений період.

Таким чином, рецензована монографія О.С. Дудченко «Конституційно-правові засади створення й функціонування органів державної влади та управління радянської України в 1920-х - першій половині 1930-х років» є важливим етапом у дослідженні правових та організаційних засад створення та функціонування органів державної влади та управління України та є завершеним науковим дослідженням, актуальним для науки історії держави і права. 